\title{
PENGENDALIAN KUALITAS PRODUK NPK PHONSKA DENGAN METODE STATISTICAL PROCESSING CONTROL PADA UNIT PRODUKSI 2A PT. PETROKIMIA GRESIK.
}

\author{
Abdurrahan Faris Indriya Himawan, M. Abidhin Al Habtsi \\ Progam Studi Manajemen \\ Fakultas Ekonomi- Universitas Muhammadiyah Gresik \\ Jl. Sumatra No. 101 GKB Gresik 61121 Jawa Timur Indonesia
}

\begin{abstract}
This study aims to determine the quality control of Phonska NPK fertilizer using Statistical Processing Control method. Statistical Processing Control to analyze and identify quality deviations in Phonska NPK products. There were five people in this study. Data collection techniques using observation, interviews and documentation. Data analysis techniques using Statistical Processing Control. PT. Petrokimia Gresik has Phonska NPK fertilizer products whose production has deviations but can be overcome using the SPC method (Statistical Processing Control).
\end{abstract}

Keywords: Statistical Processing Control, quality control, quality deviation

\section{PENDAHULUAN}

Indonesia merupakan negara agraris dimana Pertanian menjadi salah satu sektor usaha yang memiliki peran penting dalam pertumbuhan ekonomi Indonesia. Pertanian mempunyai kontribusi sebesar $0,53 \%$ terhadap pertumbuhan PDB nasional (Badan Pusat Statistik, 2015). Salah satu kontribusi dalam sektor pertanian adalah menjadi produsen bahan pangan bagi penduduk Indonesia yang jumlahnya semakin bertambah setiap tahunnya. Oleh sebab itu, produktivitas tanaman pangan harus selalu ditingkatkan agar kebutuhan pangan dapat dipenuhi yang juga semakin meningkat.

Meningkatnya kebutuhan pupuk oleh petani saat ini mendorong beberapa perusahaan pupuk termasuk untuk membuat produk yang berkualitas. Kebutuhan produk yang berkualitas amatlah penting. Kualitas suatu produk mutlak harus dijaga dan dikontrol sebagai jaminan pada konsumen bahwa produk yang berada di pasaran memiliki kualitas yang baik, sehingga perusahaan dapat bersaing dan memenangkan kompetisi dalam menarik kepercayaan pelanggan. Pengendalian kualitas merupakan aktivitas keteknikan dan manajemen yang dengan aktivitas tersebut dapat diukur ciri-ciri kualitas dari produk yang ada, membandingkannya dengan spesifikasi atau persyaratan, dan mengambil tindakan yang sesuai apabila ada perbedaan antara penampilan yang sebenarnya dan yang standar. Menurut American society for Quality (ASQ): (www.asq.org:2015) dalam buku Heizer dan Render menyatakan bahwa, kualiatas adalah keseluruhan fitur dan karakteristik sebuah produk atau jasa yang mengandalkan pada kemampuannya untuk memuaskan kebutuhan yang dijanjikan dan tersirat. Suatu Produk memiliki kualitas apabila sesuai dengan standar kualitas yang telah ditentukan. Menurut Philip B. Crosby (dalam Prihantoro, 2012:42) mutu adalah kesesuaian dengan kebutuhan yang meliputi availability, delivery, reliability, maintainability, dan cost effectiveness yang kemudian pengertian mutu itu sendiri lebih ditekankan pada aspek zero deffect.

Faiz Al Fakri (2010) Melakukan penelitian tentang "Analisis Pengendalian Kualitas Produksi di PT. Masscom Graphy Dalam Upaya Mengendalikan Tingkat Kerusakan Produk Menggunakan Alat Bantu Statistik" . Variabel Penelitian adalah adanya penyimpangan standar mutu yang dihasilkan perusahaan karena terjadi ketidaksesuaian dengan spesifikasi yang diharapkan perusahaan. Metode yang digunakan adalah peta kendali $\mathrm{p}$ ( $\mathrm{p}$-chart) dengan diagram sebab akibat (fishbone diagram) sebagai bagian dari penggunaan alat statistik untuk mengendalikan kualitas. 
Hasil penelitian menujukkan bahwa terjadinya penyimpangan mutu disebabkan oleh kesalahan-kesalahan pada proses pembuatannya, yaitu material, teknik

pembuatan, dan faktor pekerja. Dengan pelaksanaan pengendalian kualitas dengan menggunakan alat bantu statistik yang dilakukan oleh perusahaan dapat menurunkan persentase terjadinya kesalahan dalam proses produksi perusahaan.

\section{Kualitas}

Crosby (dalam Nasution, 2010:2) menyatakan bahwa kualitas adalah conformance to requirement, yaitu sesuai dengan yang disyaratkan atau distandarkan. Suatu produk memiliki kualitas apabila sesuai dengan standar kualitas yang telah ditentukan. Standar kualitas meliputi bahan baku, proses produksi dan produk jadi.

(Fahmi, 2012:46) Mutu merupakan suatu usaha yang dilakukan secara serius dengan tujuan agar tercapainya suatu nilai yang mampu memberi kepuasan secara maksimal kepada pemakainya.

\section{Dimensi Kualitas}

Gravin (dalam Nasution, 2010:4-5) mengidentifikasi delapan dimensi kualitas yang dapat digunakan untuk menganalisis karakteristik kualitas suatu barang, yaitu sebagai berikut:

1. Performa (performance) berkaitan dengan aspek fungsional dari produk dan merupakan karakteristik utama yang dipertimbangkan pelanggan ketika ingin membeli suatu produk.

2. Keistimewaan (features), merupakan aspek kedua dari performansi yang menambah fungsi dasar, berkaitan dengan pilihan-pilihan dan pengembangannya

3. Keandalan (reliability), berkaitan dengan kemungkinan suatu produk berfungsi secara berhasil dalam periodewaktu tertentu di bawah kondisi tertentu. Dengan demikian, keandalan merupakan karakteristik yang merefleksikan kemungkinan tingkat keberhasilan dalam penggunaan suatu produk, misalnya keandalan mobil adalah kecepatan.

4. Konformansi (conformance), berkaitan dengan tingkat kesesuaian produk terhadap spesifikasi yang telah ditetapkan sebelumnya berdasarkan keinginan pelangggan.

5. Daya tahan (durability), merupakan ukuran masa pakai suatu produk

6. Kemampuan pelayanan (service ability), merupakan karakteristik yang berkaitan dengan kecepatan/kesopanan, kompetensi, kemudahan, serta akurasi dalam perbaikan.

7. Estetika (aesthetics), merupakan karakteristik mengenai keindahan yang bersifat subjektif sehingga berkaitan dengan pertimbangan probadi dan refleksi dari preferensi atau pilihan individual.

8. Kualitas yang dipersepsikan (perceived quality), bersifat subjektif, berkaitan dengan perasaan pelanggan dalam mengkonsumsi produk, seperti meningkatkan harga diri.

\section{Perspektif Kualitas}

Garvin (dalam Nasution, 2010:6-7) mengidentifikasi adanya lima alternatif perspektif kualitas yang biasa digunakan, yaitu:

1. Trancendental Approach, menurut pendekatan ini kualitas dapat dirasakan atau diketahui, tetapi sulit dioperasionalkan. Sudu pandang ini biasanya diterapkan dalam seni musik, drama, seni tari, dan seni rupa. Selain itu perusahaan dapat mempromosikan produknya dengan pernyataanpernyataan seperti tempat berbelanja yang menyenangkan (supermarket), elegan (mobil), kecantikan wajah (kosmetik), kelembutan dan kehalusan kulit (sabun mandi), dan lain-lain. Dengan demikian, fungsi perencanaan, produksi dan pelayanan suatu perusahaan sulit sekali menggunakan definisi seperti ini sebagai dasar manajemen kualitas karena sulitnya mendesain produk secara tepat yang mengakibatkan implementasinya sulit.

2. Product-based Approach, pendekatan ini menganggap kualitas sebagai 
karakteristik atau atribut yang dapat dikuantifikasikan dan dapat diukur. Perbedaan dalam kualitas mencerminkan perbedaan dalam jumlah unsur atau atribut yang dimiliki produk. Karena pandangan ini sangat objektif, maka tidak dapat menjelaskan perbedaan dalam selera, kebutuhan, dan preferensi individual.

3. User-based Approach, pendekatan ini didasarkan pada pemikiran bahwa kualitas tergantung pada orang yang menggunakannya, dan produk yang paling memuaskan preferensi seseorang (misalnya perceived quality) merupakan produk yang berkualitas paling tinggi. Perspektif yang subjektif dan demand-oriented ini juga menyatakan bahwa pelanggan yang berbeda memiliki kebutuhan dan keinginan yang berbeda pula, sehingga kualitas bagi seseorang adalah sama dengan kepuasan maksimum yaang dirasakannya.

4. Manufacturing-based Approach, perspektif ini bersifat dan terutama meperhatikan praktik-praktik perekayasaan dan pemanufakturan serta mendefinisikan kualitas sebagai sama dengan persyaratannya(conformance to requirements). Dalam sektor jasa, dapat dikatakan bahwa kualitasnya bersifat operation-driven. Pendekatan ini berfokus pada penyesuaian spesifikasi yang dikembangkan secara internal, yang sering kali didorong oleh tujuan peningkatan produktivitas dan penekanan biaya. Jadi, yang menentukan kualitas adalah standarstandar yang ditetapkan perusahaan, bukan konsumen yang menggunakannya.

5. Value-based Approach, pendekatan ini memandang kualitas dari segi nilai dan harga. Dengan mempertimbangkan trade-off antara kinerja produk dan harga, kualitas didefinisikan sebagai "affordable excellence". Kualitas dalam perspektif ini bersifat relatif, sehingga produk yang memiliki kualitas paling tinggi belum tentu produk yang paling bernilai. Akan tetapi, yang paling bernilai adalah produk atau jasa yang paling tepat dibeli (best buy).

\section{Pengendalian Kualitas}

Pengendalian kualitas merupakan salah satu tehnik yang perlu dilakukan mulai dari sebelum proses produksi berjalan hingga proses berakhir dan menghasilkan produk yang dihasilkan. Pengendalian kualitas dilakukan untuk memenuhi standar perusahaan yang diinginkan sehingga konsumen atau pelanggan puas akan produk atau jasa yang diberikan.

Adapun pengertian pengendalian kualitas menurut beberapa ahli :

1. Menurut Raviato (dalam Prihantoro, 2012:4) pengendalian kualitas yaitu melakukan perencanaan, pengerjaan atau proses, pengecekan atau evaluasi dan aksi perbaikan terhadap masalah yang berkaitan dengan kualitas.

2. Pengertian pengendalian kualitas menurut Sofjan Assauri (1998:210) adalah "pengawasan mutu merupakan usaha untuk mempertahankan mutu/kualitas barang yang dihasilkan, agar sesuai dengan spesifikasi produk yang telah ditetapkan berdasarkan kebijaksanaan pimpinan perusahaan".

Tujuan Pengendalian Kualitas

Adapun tujuan dari pengendalian kualitas menurut Sofjan Assauri (1998:210) adalah :

1. Agar barang hasil produksi dapat mencapai standar kualitas yang telah ditetapkan.

2. Mengusahakan agar biaya inspeksi dapat menjadi sekecil mungkin.

3. Mengusahakan agar biaya desain dari produk dan proses dengan menggunakan kualitas produksi tertentu dapat menjadi sekecil mungkin.

4. Mengusahakan agar biaya desain dari produk dan proses dengan menggunakan kualitas produksi tertentu dapat menjadi sekecil mungkin.

Tujuan utama pengendalian kualitas adalah untuk mendapatkan jaminan bahwa kualitas produk atau jasa yang dihasilkan sesuai dengan standar kualitas yang telah 
ditetapkan dengan mengeluarkan biaya yang ekonomis atau serendah mungkin.

Pengendalian kualitas tidak dapat dilepaskan dari pengendalian produksi, karena pengendalian kualitas merupakan bagian dari pengendalian produksi. Pengendalian produksi baik secara kualitas maupun kuantitas merupakan kegiatan yang sangat penting dalam suatu perusahaan. Hal ini disebabkan karena kegiatan produksi yang dilaksanakan akan dikendalikan, supaya barang atau jasa yang dihasilkan sesuai dengan rencana yang telah ditetapkan, dimana penyimpangan-penyimpangan yang terjadi diusahakan diminimumkan.

Pengendalian kualitas juga menjamin barang atau jasa yang dihasilkan dapat dipertanggungjawabkan seperti halnya pada pengendalian produksi, dengan demikian antara pengendalian produksi dan pengendalian kualitas erat kaitannya dalam pembuatan barang.

\section{Hubungan Mutu Dan Produktivitas}

Pengukuran umum produktivitas memang sangat erat dengan pengukuran efisiensi dan penggunaan. Namun pengukuran terbaru dalam produktivitas telah melibatkan kualitas didalamnya. Menurut Shaw (1989), perbaikan produktivitas adalah lebih baik daripada sekedar mengadakan pengurangan karyawan, namun produktivitas dapat ditingkatkan dengan cara mengerjakan lebih banyak dengan sumber daya yang sama, mengerjakan lebih sedikit dengan pengurangan sumber daya yang lebih besar, atau mengerjakan lebih sedikit dengan mengkonsumsi sumber daya yang lebih sedikit

\section{Alat Bantu Pengendalian Kualitas Statistik.}

Pengendalian kualitas secara statistik dengan menggunakan SPC (Statistical Processing Control) mempunyai 7 (tujuh) alat statistik utama yang dapat digunakan sebagai alat bantu untuk mengendalikan kualitas sebagaimana disebutkan juga oleh Heizer dan Render dalam bukunya Manajemen Operasi (2010; 254-257), antara lain yaitu; check Sheet, histogram,

agram pareto, diagam sebab akibat, scatter diagram, dan diagram proses.

$\begin{array}{ll}\begin{array}{l}\text { Pengendalian } \\ \text { (Statistical Processing Control). }\end{array} & \text { Statistik } \\ & \end{array}$

Menurut Hazer dan Rander (2010:276) Pengendalian kualitas statistik atau statistical processing control adalah suatu proses yang digunakan untuk memonitor standar dengan menetapkan pengukuran dan tindakan korektif atas suatu produk atau jasa yang dihasilkan.

Sedangkan menurut Montogomery (dalam Prihantoro, 2012:98) statistik adalah seni pengambilan keputusan tentang suatu proses atau populasi berdasarkan suatu analisis informasi yang terkandung di dalam suatu sampel dari populasi itu. Metode statistik memainkan peranan penting dalam jaminan kualitas. Metode statistik itu memberikan cara-cara pokok dalam pengambilan sampel produk, pengujian serta evaluasinya dan informasi di dalam data itu digunakan untuk mengendalikan dan meningkatkan proses pembuatan. Lagi pula statistik adalah bahasa yang digunakan oleh insyinyur pengembangan, pembuatan, pengusahaan, manajemen dan komponenkomponen fungsional bisnis yang lain untuk berkomunikasi tentang kualitas.

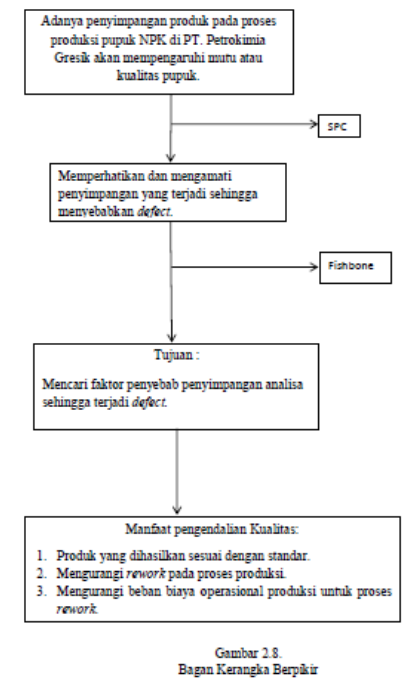

\section{METODOLOGI PENELITIAN}

Jenis penelitian yang digunakan adalah penelitian kualitatif dimana penelitiannya dilakukan pada kondisi yang alamiah (natural setting). Penelitian dilakukan pada obyek yang alamiah. Obyek yang alamiah adalah obyek yang berkembang apa adanya, tidak dimanipulasi oleh peneliti dan kehadiran peneliti tidak begitu 
mempengaruhi dinamika pada obyek tersebut. Dalam penelitian kualitatif instrumennya adalah orang atau human interest, yaitu peneliti itu sendiri. Analisis data yang dilakukan bersifat induktif berdasarkan fakta-fakta yang ditemukan di lapangan dan kemudian dikonstruksikan menjadi hipotesis atau teori. Penelitian kualitatif tidak menekankan pada generalisasi, tetapi lebih pada makna (Sugiyono, 2012:14).

Unit analisis pada penelitian ini adalah adalah exisisting produksi atau proses produksi pupuk NPK PHONSKA yang ada unit 2A PT. Petrokimia Gresik, serta unit perencanaan dan pengendalian produksi.

Informan penelitian adalah orang yang dimanfaatkan untuk memberikan informasi tentang situasi dan kondisi latar belakang penelitian dan merupakan orang yang benarbenar mengetahui permasalahan yang akan diteliti. (Moleong 2015;163). Dalam penelitian ini terdapat 2 (dua) informan yaitu, informan kunci dan informan non kunci.

Dalam teknik pengumpulan data pada penelitian ini menggunakan teknik triangulasi, triangulasi diartikan sebagai teknik pengumpulan data yang bersifat menggabungkan dari beberapa teknik pengumpulan data dan sumber data yang telah ada. Peneliti menggunakan observasi, wawancara mendalam dan dokumentasi untuk sumber data yang sama.

Teknik Analisis Data yang digunakan dalam penelitian ini menggunakan metode SPC (Statistical Processing Control).

Pengujian keabsahan data penelitian ini menggunakan triangulasi teknik. Triangulasi teknik dalam pengujian kredebilitas data dilakukan dengan cara mengecek data kepada sumber yang sama dengan teknik yang berbeda

\section{HASIL PENELITIAN}

PT Petrokimia Gresik berdiri pada tahun 1962 dengan nama Proyek Petrokimia Surabaya. Perusahaan ini merupakan Badan Usaha Milik Negara (BUMN) yang bergerak di bidang produksi pupuk dan bahan-bahan kimia. Kontrak pembangunan Proyek Petrokimia Surabaya dibentuk berdasarkan MPRS No. II Tahun 1960 yang kemudian disebut sebagai Proyek Prioritas dalam Pola Pembangunan Nasional Berencana Tahap I (1961-1969) serta didukung dengan adanya surat Keputusan Presiden RI No. 260 Tahun 1960. Penandatanganan atas proyek ini dilakukan pada tanggal 10 Agustus 1964 dan mulai diberlakukan pada tanggal 8 Desember 1964. Pembangunan proyek ini sempat terhenti pada tahun 1968 akibat krisis ekonomi yang dialami oleh Indonesia. Namun, proyek kembali dilanjutkan atas dasar surat Keputusan Presidium Kabinet Ampera No.B/891/Preskab/4/1967. Pada tanggal 10 Juli 1972 proyek diresmikan dan ditetapkan sebagai hari jadi PT Petrokimia Gresik.

PT Petrokimia Gresik berada di Kabupaten Gresik, Jawa Timur dengan lahan seluas 450 Ha. Pemilihan lokasi ini ditentukan berdasarkan hasil studi kelayakan pada tahun 1962 yang dilakukan oleh Badan Persiapan Proyek-Proyek Industri (BP3I) yang dikoordinir oleh Departemen Perindustrian Dasar dan Pertambangan.

Departemen Produksi IIA adalah salah satu unit kerja dibawah Kompartemen Pabrik II. Departemen Produksi IIA mempunyai 4 (empat) unit produksi, yaitu Pabrik Pupuk Fosfat (PF I), Pabrik Pupuk Phonska I, II, dan III.

Proses produksi di Pabrik Phonska I,II,III secara garis besar memiliki persamaan baik dari persiapan bahan baku hingga pengeluaran produk akhir. Perbedaan terdapat pada kapasitas produksinya dimana Phonska I mampu memproduksi hingga 1500 ton/hari (450.000 ton/tahun) sedangkan Phonska II dan III mampu memproduksi hingga 2000 ton/hari (masing-masing 600.000 ton/tahun). Selain itu, perbedaan antara Phonska I dengan Phonska II-III adalah proses Phonska I menggunakan pug mill sebagai pre mixed bahan baku padat dengan recylce material sedangkan pada Phonska II-III tidak menggunakan karena pre mixed terjadi di recycle drag conveyor dimana bahan baku padat bertemu dengan recylce material. Perbedaan terakhir adalah posisi polishing screen di Phonska I berada sebelum Cooler, sedangkan pada Phonska II-III posisi polishing screen berada setelah Cooler. 


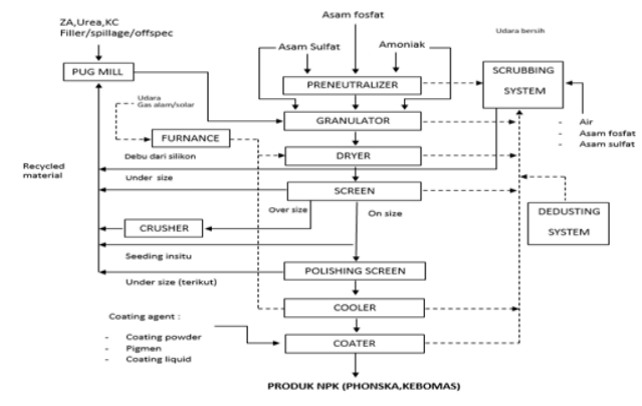

Analisis Data

Analisis Data yang digunakan untuk rumusan masalah yang ada dalam penelitian ini menggunakan metode SPC (Statistical Processing Control), menggunakan fishbone diagram, kemudian analisis kualitatif deskriptif.

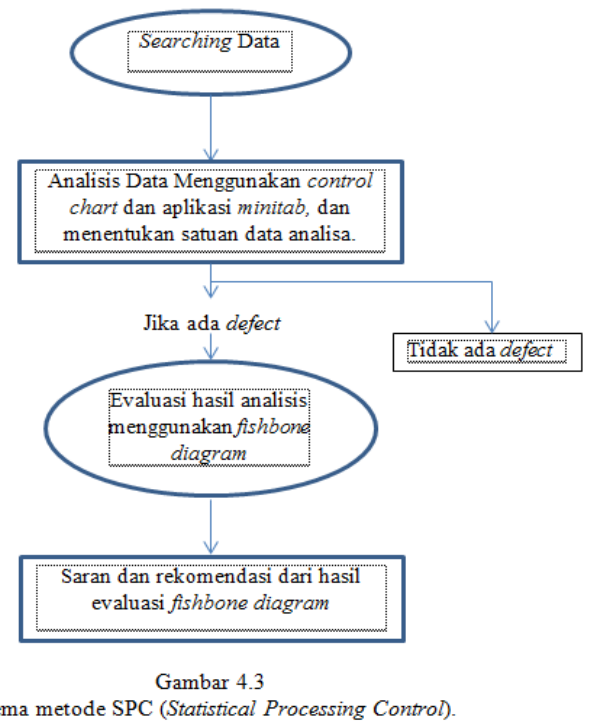

Analisa dilakukan untuk

mengetahui instruksi kerja kinerja telah memenuhi unsur-unsur instruksi kerja, peta kendali dan kualitas produk akhir Phonska telah terkendali dan analisis kemampuan proses tersebut terkontrol.

Selain itu, analisa dilakukan untuk mengetahui pengaruh faktor kadar kandungan $\mathrm{N}, \mathrm{P}$ dan $\mathrm{K}$ pada produk Phonska. Dalam tahap ini dilakukan analisa mengenai pemenuhan instruksi kerja penentuan Quality Control produk akhir Phonska yang telah dibuat terhadap unsurunsur yang dibutuhkan seperti tujuan, ruang lingkup, definisi, standar mutu produk akhir, tanggung jawab, instruksi kerja dan dokumentasi pelaporan

Pengumpulan data dibagi menjadi 2, data parameter dan Analisa bulanan kadar N,P dan $\mathrm{K}$ produk Phonska 15-15-15 dengan toleransi $\pm 1,2 \%$ dimana untuk batas atas UCL (Upper Control Limit) 16,2\% dan untuk batas bawah LCL (Lower Control Limit) berada di angka 13,8\%. Sedangkan untuk pengolahan data digunakan metode Statistical Processing Control (SPC) dan aplikasi minitab.

\section{Kapabilitas Proses (Cp)}

Perhitungan kapabilitas proses (Cp) dilakukan dengan tujuan untuk mengetahui kapabilitas dari proses pencampuran $\mathrm{N}$, $\mathrm{P}_{2} \mathrm{O}_{5}$, dan $\mathrm{K}_{2} \mathrm{O}$ dalam proses granulasi kondisi eksisting. Batasan yang digunakan menggunakan batasan yang telah diberikan oleh pihak manajemen yaitu 13.8-16.2 persen. Untuk menentukan nilai Cp diperlukannya standar deviasi $(\delta)$ proses granulasi tersebut. Nilai standar deviasi ini didapatkan dari perhitungan $\mathrm{R}$ dibagi dengan d2 Dari perhitungan kapabilitas proses $(\mathrm{Cp})$, didapatkan nilai kapabilitas proses eksisting $\mathrm{N}=0.5016 ， \mathrm{P}=0.3611$ dan $\mathrm{K}=0.2130$ dari ketiga hasil perhitungan kapabilitas proses, nilai kapabilitas untuk kandungan N, P2O5, dan $\mathrm{K} 2 \mathrm{O}$ kurang dari satu, dimana angka 1 merupakan angka ideal untuk suatu kondisi proses sehingga dapat dikatakan capable. Maka dengan itu dapat dikatakan bahwa kapabilitas proses granulasi NPK dalam proses menjaga kandungan $\mathrm{N}, \mathrm{P} 2 \mathrm{O} 5$, dan $\mathrm{K} 2 \mathrm{O}$ pada phonska masih belum bisa dikatakan capable.

Mengidentifikasi Faktor - faktor Penyebab Defect

Alat bantu yang digunakan dalam mengidentifikasi faktor - faktor penyebab produk defect yaitu berupa fishbone diagram, yang diperoleh dari hasil wawancara kepada para informan, dan dokumentasi data analisa melalui aplikasi minitab.

Berdasarkan hasil pembuatan fishbone diagram, serta memperhitungkan proses produksi eksisting yang sudah ada pada pabrik Phonska 2 dan 3, maka dengan itu dapat diberikan disimpulkan sebagai berikut 
a. Personel / Man

Proses produksi pabrik pupuk adalah continous production, yang berarti pabrik memproduksi selama 24 jam non-stop. Meskipun berjalan 24 jam non-stop semua pekerjaan proses produksi pupuk NPK Phonska dikerjakan dengan mesin sedangkan manusianya sendiri atau operator hanya memantau berjalannya proses produksi tersebut. Dari hasil wawancara yang didapat dari informan kunci dan non kunci dalam berjalannya kegiatan proses produksi tidak ada masalah SDM yang dapat mempengaruhi berjalannya proses produksi sehingga muncul produk yang meyimpang dari standar atau defect. Dari teman-teman operator sendiri seperti mas Helmi dan mas Anam mengaku pelatihan yang diberikan oleh perusahaan dirasa cukup karena hampir setahun sekali diadakan penyegaran pengetahuan pabrik atau training internal yang diadakan oleh perusahaan khusus para operator proses produksi. Sehingga harapan dari perusahaan para karyawan khusunya operator produksi mempunyai skill yang sesuai dengan diharapka agar proses produksi berjalan lancar. Hal ini juga didukung dengan adanya kegiatan rolling operator sehingga para operator diharapkan benar-benar paham disetiap bagian sehingga operasi produksi bisa berjalan dengan baik seperti yang disampaikan pak Yudhi Wijaya selaku wakabag Phonska II/III.

Jam operasional produksi sendiri dibagi menjadi 3 shift yaitu pagi mulai pukul 07.00-15.00, shift sore pukul 15.00-23.00 dan shift malam 23.00-07.00. maka dari itu untuk jam kerja shift dibentuk menjadi 4 grup kerja yaitu grup ABCD dimana jadwal jam kerja sudah diatur dari perusahaan. Meskipun jam kerja yang berbeda koordinasi antar grup tetap terjaga agar kualitas dari produksi sendiri bisa tetap terjaga seperti yang disampaikan mas Anam selaku operator shift proses produksi. Kalaupun koordinasi tetap terjaga tapi masih ada produk yang tidak sesuai dengan standar analisa bisa jadi kemungkinan penyebabnya adalah karena material ataupun equipment.

b. Material

Bahan baku merupakan salah satu hal terpenting dalam proses produksi, namun terkadang terdapat beberapa bahan baku yang memiliki kandungan unsur atau karakteristik yang terkadang tidak sesuai. Menurut data dari informan kunci maupun non kunci, untuk bahan baku pembuatan pupuk NPK untuk N biasanya menggunakan bahan baku padatan berupa Urea dan ZA kemudian ditambah liquid dari PN yang merupakan reaksi amoniak, asam sulfat dan asam phospat. Untuk unsur P nahan bakunya berasal dari Asam Phosphat yang di supply dari utilitas. Sedangkan untuk analisa K nya kita ambil dari KCL. KCL sendiri dibagi menjadi 3 yaitu KCL merah, KCL putih, dan KCL sembur. Permasalahan pada material ini biasanya terjadi dalam proses rasio penambahannya pada saat proses reaksi, rasio yang digunakan setiap material sudah ada ukuran yang ditetapkan dari candal sebagai patokan atau SOP dalam reaksi proses. Akan terkadang fakta dilapangan tidak sesuai dengan teori yang ada dikarenakan proses reaksi kimia sendiri tidak bisa diukur secara pasti.

Kemudian bahan baku sendiri terkadang diperoleh dari internal atau perusahaan sendiri ada juga yang impor dari luar negeri. Untuk material yang impor terkadang karakteristik materialnya tidak sesuai dengan spesifikasi. Kan tetapi hal ini dilakukan oleh pihak manajemen karena untuk mengantisipasi habisnya bahan baku agar proses produksi biar tetap berjalan.

Seperti bahan baku Urea impor yang digunakan itu produknya terlalu lembab atau basah sehingga biasanya mengakibatkan kebuntuan di dozometer sama halnya bahan baku ZA impor yang karakteristikproduknya basah sehingga gampang buntu ketika masuk di dozometer. Untuk KCL sendiri penggunaanya biasanya sesuai dengan mood operationnya kadang untuk diawal produksi teman-teman operator lebih senang menggunakan KCL merah karena bahan bakunya lembut dan mudah dalam proses granulasi.KCL sembur dan putih biasanya juga digunakan ketika proses produksinya sudah berjalan normal.

\section{c. Machine / Mesin}

Mesin merupakan equipment yang harus diperhatikan performanya karena harus berada pada keadaan dan kondisi yang baik agar proses produksi dapat berjalan dengan lancar, namun tidak menuntut kemungkinan 
akan terjadi kerusakan pada mesin atau pun keakuratan dari alat ukur yang digunakan. Kerusakan atau ketidakakuratan tersebut dapat berpengaruh pada ketidakseimbangan kadar NPK sehingga produk yang dihasilkan tidak sesuai spesifikasi. Untuk kendala ketidakakuratan alat ukur ini disebabkan mesin yang bersifat dinamis/ mesin berjalan terus menerus sehingga dengan berjalannya waktu keakuratan mesin menurun. selain itu, getaran yang dihasilkan selama proses produksi dan load produksi yang tinggi dapat menurunkan keakuratan alat ukur sehingga perlu dilakukan kalibrasi agar dapat bekerja sesuai fungsinya. Tidak menutup kemungkinan juga problem pada alat operasi dipengaruhi karena karakteristik material bahan baku yang tidak sesuai, contohnya alat dozometer sebagai equipment yang mengatur besaran input bahan baku agar formulasi analisa sesuai dengan standar, maka dari itu equipment tersebut rawan terjadinya missing sehingga perlu sering dikalibrasi. Kendala yang kedua yaitu mesin shutdown/breakdown yang disebabkan beberapa faktor seperti cleaning outlet, listrik mati,conveyor putus dan lainlain. Kemudian untuk bahan baku yang bersifat liquid biasanya sering terjadi masalah pada pompanya misal pompa amoniak atau asam phospaht drop maka akan mempengaruhi proses granulasi sehinggga produk tidak dapat menjadi butirn pupuk dikarenakan kandungan atau kadar analisanya tidak sesuai diakibatkan pompa tidak mampu bekerja secara maksimal.

Kemudian control valve, merupakan equipment yang mengatur besar kecilnya input material agar rasio bahan baku bisa sesuai sehingga produk yang diharapkan bisa sesuai dengan analisa. Fungsi dari control valve hampir sama dengan dozo meter. Untuk item yang digunakan svt-341, svt-342, svt-343 yaitu control valve amoniak, asam phosphat, dan asam sulfat. Maka dari itu untuk control valve sendiri perlu sering dilakukan kalibrasi agar rasio material yang digunakan akurat dan tidak ada pemborosan.

\section{SIMPULAN}

Kesimpulan

Kesimpulan dari penelitian mengenai "Pengendalian Kualitas Produk NPK
Phonska Dengan Metode Statistical Processing Control Pada Unit Produksi 2A PT. Petrokimia Gresik" adalah sebagai berikut :

1. Adanya penyimpangan kualitas pada proses produksi NPK Phonska utamanya dalam unsur analisa kadar NPK Phonska. Untuk unsur $\mathrm{N}$ terdapat penyimpangan selama 5 hari, untuk unsur $\mathrm{P}$ analisa yang menyimpang terdapat 5 hari, untuk unsur $\mathrm{K}$ terdapat penyimpangan selama 4 hari

2. Adanya proses produksi yang tidak capable di setiap unsur hara NPK Phonska.

3. Penyebab utama adanya penyimpangan pada analisa proses produksi kalau dilihat dari material dikarenakan adanya input kualitas material bahan baku yang tidak sesuai kemudian kadar yang tidak sesuai juga berpengaruh. Untuk mesinnya bisa disebabkan adanya ketidak akurasian pada mesin dan instrumentasi terutama di dozometer, dan control valve, Sehingga produk yang dihasilkan analisa yang didapatkan tidak sesuai dengan standar yang ditentukan oleh perusahaan. Sedangkan dari segi metode bisa disebabkan karena sampling yang dilakukan hanya 4 jam sekali dan itu memakan waktu yang cukup lama.

\section{Rekomendasi}

Adapun rekomendasi yang diberikan sehubungan dengan hasil penelitian penelitian tersebut :

1. Untuk Material sebaiknya memilih yang benar - benar sesuai dengan spesifikasi yang sesuai. Dan yang biasanya sesuai dengan mood operationnya, sehingga harapannya output produk yang diharapkan bisa sesuai.

2. Adanya kegiatan Preventive Maintanance setiap harinya sehinggga mesin atau equipment serta alat instrumentasi benar - benar bisa bekerja secara optimal.

3. Sering diadakannya training bagi para operator, walaupun dari sisi SDM tidak ada problem. Akan tetapi hal ini perlu agar kompetensi para operator 
meningkat dan lebih tanggap dalam menanggapi troubleshooting.

\section{DAFTAR PUSTAKA}

Assauri, Sofyan, 2008, Manajemen Produksi dan Operasi, Lembaga Penerbit Fakultas Ekonomi Universitas Indonesia, Jakarta.

Heizer, J, dan Barry R., 2015, Manajemen Operasi (Operations Manajemen), Edisi 11, Salemba empat, Jakarta.

Heizer, J, dan Barry R., 2014, Manajemen Operasi (Operations Manajemen), edisi 10, Salemba empat, Jakarta.

Lexy J. Moloeng, 2015, Metode Penelitian Kualitatif, Remaja Rosdakarya, Bandung.

Nasution, M. Nur, 2010, Manajemen Mutu Terpadu, Ghalia Indonesia, Bogor.

Prihantoro, Rudy, 2012, Konsep Pengendalian Mutu, Remaja Rosdakarya, Bandung.
Fahmi, Irham, 2012, Manajemen Produksi dan Operasi, Alfabeta, Bandung.

Tannady, Hendy, 2015, Pengendalian Kualitas, Graha Ilmu, Yogyakarta.

Tjiptono, Fandy dan Anastasia Diana, 2003, Total Quality Management, CV Andi Offset, Yogyakarta.

Gasperz, Vincent, 2003, Total Quality Management, Gramedia Pustaka Utama, Jakarta.

Heizer, J, dan Barry R., 2014, Manajemen Operasi (Operations Manajemen), edisi 10, Salemba empat, Jakarta.

Sugiyono, 2010, Memahami Penelitian Kualitatif, Alfabeta, Bandung.

http://ilmumanajemenindustri.com/qc-seventools-tujuh-alat-pengendalian-kualitas/

https://teknikmanajemenindustri.wordpress.c om/2010/10/27/seven-tools-quality-

management/

www.petrokimia-gresik.com

https://sites.google.com/site/kelolakualitas/ta bel-nilai-A2d2D3D4

http://web.mit.edu/2.810/www/files/readings /ControlChartConstantsAndFormulae.pdf 